2019 (111): 43-62.

(C) A szerző(k) 2019

replika.hu/replika/111

\title{
Tomay Hyra
}

\section{Az összekötő társadalmı tôke [újra]termelódésének tereı}

\author{
A városı és vidékı dzsentrıfıkácı́ szerepe \\ a vállalkozóı és Innovácıós ökoszısztémákban
}

\begin{abstract}
Absztrakt: A társadalmi tőke, és különösen az összekötő társadalmi tőke magas foka számos tanulmány és szerző által bizonyítottan pozitív hatással van a gazdasági növekedésre, serkentőleg hat a vállalkozói és innovációs kedvre, ezáltal kedvez a vállalkozói ökoszisztéma kialakulásának. Másfelől a dzsentrifikáció, azaz bizonyos városi térségek felértékelődése, és előbb a kreatív középosztály, majd a felső középosztály ezen helyeken történő koncentrációja évtizedek óta vezető kutatási területe a városszociológiának, illetve az utóbbi időben a vidékszociológiában is megjelent ez a kutatási irányzat. Jelen tanulmány célja, hogy ezt a két jelenséget összekapcsolja, és a nemzetközi szakirodalomra támaszkodva azt vizsgálja, miként hat a dzsentrifikáció, azaz a föként kreatív (müvész, értelmiségi) foglalkozású népesség tömörülése és egymással, illetve a felső középosztállyal való rendszeres találkozása akár egy-egy városrészben, akár egy kis faluban vagy az ott rendezett fesztiválokon az összekötő társadalmi tőke (újra)termelésére, és hozzájárulhat-e ez a folyamat az innováció és a vállalkozások fellendüléséhez az adott térségben, illetve városrészben. Tekintettel arra, hogy a témában még nem készült empirikus kutatás, a jelen tanulmány a különböző elméleti és kutatási irányokhoz tartozó szakirodalmak összefésülésével, kritikai értelmezésével egyfajta konceptuális keretet szeretne felvázolni egy ilyen irányú jövőbeli kutatás számára.
\end{abstract}

Kulcsszavak: társadalmi tőke, összekötő társadalmi tőke, dzsentrifikáció, vidéki dzsentrifikáció, vállalkozói és innovációs ökoszisztéma 


\section{Bevezetés}

Kétségtelen tény, hogy manapság az innováció és a vállalkozások a gazdasági növekedés motorjai (Florida et al. 2017). Évente a világon mintegy 100 millió vállalkozás indul, közülük egyre többen innovatív üzleti modellt alkalmaznak és egyre több az egyéni vállalkozó (Sims 2017). Ugyanakkor az innováció, a vállalkozás és a kreativitás nem egyes egyének, cégek vagy művészek egyéni teljesítményei, hanem egymásra épülő társadalmi folyamatok (Florida et al. 2017). Ahhoz, hogy a kívánatos gazdasági folyamatok beinduljanak, szükség van a vállalkozások környezetét képező társadalmi-gazdasági térre, azaz a vállalkozói ökoszisztéma egészére (Szerb 2016). A társadalmi feltételeket vizsgálva a társadalmi tőke, és különösen az összekötő társadalmi tőke magas foka számos tanulmány és szerző által bizonyítottan pozitív hatással van a gazdasági növekedésre, serkentőleg hat a vállalkozói és innovációs kedvre, ezáltal kedvez a vállalkozói ökoszisztéma kialakulásának (Füzér et al. 2006; Bodor 2013; Savanya 2013). Ugyanakkor e folyamatok nem függetlenek a tértől: már régóta köztudott, hogy az innovációs centrumok a globális nagyvárosokban, illetve bizonyos régiókban (pl. Szilícium-völgy) összpontosulnak. A globális világgazdaságban felértékelödik a térségek szerepe: a lokális hálózatok ereje abban rejlik, hogy képesek pozitív externáliákat gerjeszteni, melyekhez a térségben jelenlévő és a hálózatban részt vevő szervezetek és egyének hozzáférnek, de a térségen kívüliek csak igen korlátozottan vagy nagyobb tranzakciós költséggel (Savanya 2013). Ma már ezen is túllép néhány szerző, amikor azt állítja, hogy a város, a régió nemcsak olyan hely, ahol az innováció és a vállalkozás megtörténik, hanem maga a város, az ott zajló társadalmi folyamatok azok a mechanizmusok, melyek lehetővé teszik az innováció és a vállalkozások növekedését (Florida et al. 2017).

Mind az innovációs és vállalkozói ökoszisztémák kutatása, mind a társadalmi tőke irodalma felfigyelt tehát a hely, a város szerepére ezen kedvező gazdasági folyamatok beindításában és koncentrációjában. Ugyanakkor nem általában „a város” az, ahol az innovációk koncentrálódnak, hanem a városok bizonyos részei, és hiába vizsgálják a közgazdászok egy-egy innovatív régió számos aspektusát, ami az egyikben mủködő modellnek tűnik, a másik város, régió esetében nem az. Isenberg (2010) szerint minden vállalkozói ökoszisztéma egyedi, azokat nem igazán lehet másolni és utánozni. Véleményem szerint a vállalkozói ökoszisztémák egyediségét, utánozhatatlanságát hangsúlyozó írások részben azért születhetnek, mert a legtöbb szerző nem vizsgálja részletesen azokat a térbeli-társadalmi jelenségeket, melyek az innovációk és vállalkozások gyors növekedésének beindulásáért felelnek: jelesül a kreatív vagy értelmiségi foglalkozásokat végző magas státuszú társadalmi csoport térbeli koncentrációját bizonyos kitüntetett földrajzi terekben: azaz a dzsentrifikációt.

Ebben a cikkben - a föbb fogalmak és folyamatok áttekintése után - a téma e szükebb, speciális aspektusával kívánok foglalkozni: nevesül a térbeli és társadalmi közelség szerepével az összekötő (bridging) társadalmi tőke kialakulásában és megerősítésében a középosztályi és felső középosztályi társadalmi csoportok között a dzsentrifikáció folyamata során. Tekintettel arra, hogy a témában még nem készült empirikus kutatás, jelen tanulmány a különböző kutatási irányokhoz tartozó szakirodalmak összefésülésével egyfajta konceptuális keretet szeretne felvázolni egy ilyen irányú jövőbeli lehetséges kutatás számára. 


\section{Vállalkozói és innovációs ökoszisztémák}

A 2000-es évektől a korábbi, szükebben gazdasági szemszögü, és elősorban az outputokra fókuszáló megközelítéseket felváltotta a vállalkozói és innovációs ökoszisztéma fogalmi kerete. Az innovációs ökoszisztéma fogalma egy új hálózati modellt jelent az üzleti életben és gazdaságirányításban, mely képessé teszi a vállalatokat és területeket az innovációvezérelt növekedésre és a technológiai változásokból származó haszonszerzésre (Smorodinskaya és Katukov 2017). Grünhut (2018) szerint az innovációs ökoszisztéma alapja az innovativitás, az egyéni, közösségi és társadalmi szintű szellemi megújulási készség és képesség. Eszerint az ökoszisztéma-megközelítés elsődlegesen abban különbözik az egyéb, innovációs outputokra koncentráló értelmezésektől, hogy fókuszában a társadalmi, közösségi és egyéni innovativitás áll. Az eredetileg Dan Isenberg nevéhez füződő „vállalkozói ökoszisztéma” fogalma Brown és Mason alapján „olyan egymással összeköttetésben, interakcióban álló vállalkozó szemléletü egyének, szervezetek, intézmények (egyetemek, állami ügynökségek) koncentrációja, melyben vállalkozásspecifikus folyamatok vannak jelen, és melyet formális és informális folyamatok müködtetnek, kormányoznak" (Brown és Mason, idézi Kuti és Bedő 2018: 46). Isenberg (2010) a vállalkozói ökoszisztéma hat elemét azonosította: (1) politika (szabályozás és ösztönzés, végrehajtás és tulajdonosi jogosítványok), (2) kultúra (kockázat elfogadása, hibák és kudarcok, innováció, kísérletezés), (3) tőke (mikrohitel, kockázati tőke, részvénypiacok, üzletiangyal-típusú befektetések), (4) piacok (elosztási csatornák, termelési tapasztalatok, vállalkozói hálózatok), (5) humán tőke (képzett munkaerő, vállalkozói tréning, továbbképzés), (6) támogatás (üzleti fejlesztési központok és jogi, technikai, pénzügyi kapacitások, beleértve az infrastruktúrát [telekommunikáció, energia, szállítás]). Ez azt jelenti, hogy a vállalatok beágyazódnak abba a társadalmi, kulturális, politikai és gazdasági környezetbe, amelyben müködnek (Szerb 2017), ezért sikerüket, a gazdasági növekedés facilitálását sem lehet megérteni ezen társadalmi kulturális környezet elemzése nélkül.

\section{Város, kreativitás, vállalkozások}

Az innováció és a vállalkozások földrajzát kutatók általában arra koncentrálnak, hogy megértsék az innováció földrajzi megoszlását, a térbeli együtt járást az innovatív régiók és a helyi mikrogazdasági folyamatok közt. Stam (2015) meghatározása szerint a vállalkozói ökoszisztéma olyan függőségi viszonyban lévő szereplők és tényezők összessége, melynek koordinációja nyomán termékeny vállalkozói aktivitás jön létre egy adott területi egységen belül. A Stam által az ökoszisztéma rendszerfeltételeit képező elemek kialakulásának peremfeltételei közé sorolt regionális adottságokat a regionális kutatások irodalma úgy vizsgálja, hogy a település mint földrajzi egység hogyan befolyásolja a termékeny vállalkozóiság, kreativitás és innováció terjedését (Kuti és Bedő 2018).

A szakirodalomban nagy hagyománya van a várost a kreatív folyamatok középpontjába állító írásoknak. Jacobs (1969) szerint a sokféleség az, és nem a specializáció, ami stimulálja az innovációt és a városi növekedést. Szerinte a város és a régió maga hozza össze a gazdasági szereplőket: a cégeket, tehetséget és más intézményeket és szolgáltatásokat, amelyek az innovációk és vállalkozások elindulásához kellenek. 
Az innováció és a vállalkozás sokkal inkább városi/régiós folyamatok, mint a cégek vagy az egyének tevékenysége. Florida és szerzőtársai (2017) érvelése szerint a település, a város nagyobb mértékben járul hozzá a vállalkozói aktivitás fokozódásához, mint amekkora a nagyvállalatok katalizátorhatása, az innováció és a vállalkozások nem egyszerüen a városokban koncentrálódnak, hanem megkövetelik a koncentrációt. Ennek legfőbb oka, hogy a tudásalapú kapitalizmusban a vállalkozó, innovatív és kreatív társadalmi csoportok számára kifejezetten fontos a fizikai közelség és az interakciós lehetőségek. A város és a régió a legfontosabb szervezési egység, mely összehozza a cégeket, a tehetségeket és az intézményeket. (Florida et al. 2017).

Ahogy azt több városokkal foglalkozó szakember már korábban is remélte (pl. Berg et al. 1982), több évtizedes kivándorlás és szuburbanizáció után a 21. század a „városok százada” lett a nyugati világban: fiatal értelmiségiek, fóként tudósok, technológia- és tudásalapú szakmákban dolgozók, művészek, dizájnerek és médiamunkások - akiket Florida összefoglalóan a „kreatív osztály”-nak nevezett - áramlottak (vissza) a városokba. Nagyvállalatok és technológiai start-up cégek egyként települtek vissza szuburbán irodaparkjaikból az életteli városi központokba. Ezek a folyamatok nem minden várost és nem egyformán érintettek: az első évtizedekben a globális nagyvárosokba koncentrálódott a tehetség, az ötletek, beruházások letéteményesei és a gazdasági növekedés, de miután a metropoliszok megfizethetetlenül drágák lettek, és ezáltal kiszorították azt a sokféleséget, amely innovativitásuk alapját képezte, ${ }^{1}$ ma már az új városi tudásalapú gazdaság nem csak a nagyvárosokat jellemzi: a közepes és kisvárosok (pl. a föiskolai, egyetemi városok), sőt a vidéki térségek is tudnak gazdaságilag sikeressé lenni (Florida 2018).

\section{Az összekötő (bridging) társadalmi tőke}

A társadalmi tőke fogalma népszerüségre tett szert az elmúlt évtizedekben, Bourdieu (1985) és Coleman (1990) munkáin túl elsősorban Robert Putnam (2000) Bowling Alone című kötete jelentette a fogalom széles körü társadalomtudományi elterjedésének gyökerét (Füzér et al. 2005, 2006). A társadalmi tőke (a gazdasági és kulturális tőkével szemben) kifejezetten társadalmi természetü erőforrás, amely lehetővé teszi az emberek közötti együttmüködést (Füzér 2017). Eszerint az informális kapcsolathálóknak, barátságoknak és szomszédságoknak, vagy annak, amit Putnam „schmoozing”-nak ír le, ${ }^{2}$ fontos szerepe van a bizalom és az elkötelezettség létrejöttében és növekedésében (Savage, Warde és Devine 2005).

A 2000-es évekre a társadalmi tőke koncepciója egy minden társadalmi-gazdasági egyenlőtlenség magyarázatára ráhúzható fogalommá vált. Az egyéni és kollektív előnyök számos aspektusa: az egészséges élet, a növekvő jövedelem, a demokratikus kultúra és az alacsony bünözési ráták magyarázatában is megjelent, és természetesen a gazdasági fejlődés is a társadalmi tőkének tulajdonítható ezen elképzelések szerint (Füzér 2017).

1 Ahogy J. Jacobs mondta: „amikor egy hely unalmassá kezd válni, még a gazdagok is elhagyják” (Florida et al. 2017).

2 Putnam alapján „schmoozer” az, aki aktív, de informális társadalmi életet él: vacsoravendégségeket és kerti sütögetéseket tart, eljár a barátaival, kártyázik, éjszakai életet él, látogatja a rokonokat és üdvözlőlapokat küld (Putnam 2000: 94). 
Kritikusai szerint a társadalmitőke-koncepció szélesebb körü társadalomtudományi és politikai népszerűségéért az elképzelés neoliberális társadalomfelfogása felel. Mások szerint a társadalmi tőke a „trójai faló”, mely a társadalmat mint szempontot be tudta emelni a közgazdászok, politikatudósok és politikusok gondolkodásába. Mindenesetre a népszerüség ára, hogy a koncepció egyre szélesedett, és ezáltal diffúzzá vált. A 2000-es évekre egy kisebb iparág épült a társadalmi tőke dimenzióinak és aspektusainak kibontására (Blockland és Savage 2008). A koncepciót „szétszálazó” elméletek egyik irányzata a társadalmi tőke három típusát különíti el (Woolcook, Field, Halpern, idézi: Füzér 2015: 7). Eszerint a megkötő (bonding) társadalmi tőke alatt a szoros bizalmon alapuló, olyan kapcsolathálózatokban rejlő erőforrásokat kell érteni, mint például a család vagy a baráti kapcsolatok; összekötő (bridging) társadalmi tőkén a gyengébb bizalmon alapuló, például munkatársi kapcsolatok lehetséges hasznait; míg összekapcsoló (linking) társadalmi tökén az intézményesített kapcsolatokat, például a választott képviselök és az állampolgárok viszonyaiban megtestesülö lehetőségeket (Füzér 2015, 2017).

A gazdasági-társadalmi fejlődés szempontjából elsősorban az összekötő társadalmi tőke szerepe kitüntetett, mert új erőforrásokhoz nyújt hozzáférést. Míg a túl sok megkötő társadalmi tőke ezzel szemben a kreativitás, az innováció és a vállalkozói kedv gátja lehet (Portes 1998; Robert és Heinz 2013). Kérdés, hogy hogyan jön létre a gazdasági-társadalmi fejlődésben hasznos társadalmi tőke. Az ismétlődő interakciók során fokozatosan épül fel (Wilson 1997: 746), és különböző szintjei vannak (Sander és Lowney, idézi: MurzynKupisz 2013: 36): (1) étkezés és ünnepek, (2) együtt cselekvés egy közös hobbi kapcsán, (3) szívességtétel, (4) egy közösségi ügy megvitatása, (5) egy közös cél felvállalása, (6) kapcsolatháló-építés. Ahhoz azonban, hogy ez a folyamat megindulhasson, szükség van a közösen használt térre, közösségi színterekre és találkozási pontokra, melyek lehetőséget adnak az interakciókra (Murzyn-Kupisz 2013).

\section{A társadalmi tőke térbelisége}

Az utóbbi évtizedekben a szociológiában és a közgazdaság-tudományban robbanásszerü növekedésnek indult társadalmitőke-irodalomban mindeddig relatíve kevés szó esett a társadalmi tőke térbeli vonatkozásairól.

A település- és városszociológia irodalmában már régóta fontos témák a társadalmi kapcsolatok és a bizalom - elsősorban a szomszédsági kapcsolathálók (lásd Gans 1959; BVTV 1966; Nemes és Szelényi 1967), illetve az első generációs bevándorlóknak az adott népcsoport által lakott városrészek kapcsolathálói nyújtotta előnyök (Kloosterman és Van der Leun 1999) és a biztonságérzet szempontjából. E kutatások azonban túlnyomórészt a valamely szempontból deprivált társadalmi csoportok (szegények, idősek vagy újonnan érkező, más kultúrájú bevándorlók) egymás közötti, a társadalmi tőke nyelvére fordítva megkötő (bonding) típusú kapcsolathálóinak erejéről, fontosságáról szóltak.

Másfelől a társadalmi csoportok keverését (social mixing) célzó szakirodalmak és várospolitika is föként azon alapulnak, hogy az etnikai és társadalmi csoportok térbeli keverése, vegyülése a társadalmi előnyök egyenlőbb eloszlásához vezet, azaz az előnyösebb társadalmi helyzetüekkel való ismeretség, találkozás, fizikai közelség elősegíti a sokféle és termékeny kapcsolatháló kialakulását, ezáltal - összekötő társadalmi tőkeként - hozzájárul a hátrányo- 
sabb helyzetű csoport felemelkedési lehetőségeinek javulásához, erőforrások eléréséhez, miközben a magasabb státuszúak szociális érzékenységét és a társadalmi szolidaritást is erősíti az, ha egy-egy városrészben, városnegyedben heterogén népesség lakik (lásd Kleinhans et al. 2007; Schneider 2017).

A társadalmi tőke szakirodalmának térkoncepciója általában a falvak és kisvárosok (esetleg „városi falvak”, azaz kisebb, homogén szomszédságok) és a nagyvárosok dichotómiájában tesz különbséget a társadalmi tőke tekintetében: az előbbieket erősebb közösség, magasabb társadalmi tőke jellemzi. Ez a megközelítés rímel a szociológiában a 19. századtól jelen lévő rurális-urbánus társadalmi kettősségre, amit Ferdinand Tönnies a Gemeinschaft (közösség) és Gesellschaft (társadalom) fogalompárjával hoz összefüggésbe (1983 [1887]). Ugyan Tönnies fogalompárja nem egyszerüsíthető le a vidéki és városi társadalom kettősségére, de felhasználta annak magyarázatára, hogy miért adta át a helyét a személyes, elsődleges kapcsolatokon alapuló, családközpontú és elsősorban a faluhoz kötődő élet a racionálisan szervezett, személytelen urbanizált életnek Európában (Csanádi et al. 2009).

Ez a dichotóm és statikus rurális-urbánus megközelítés azonban nem tartható fent a 21. század körülményei között (Ray 1998; Bodor et al. 2018). A mai világban a közlekedés fejlődésével és az infokommunikációs technológiák (IKT) elterjedésével a fizikai közelség, kapcsolat már nem feltétlenül szükséges a társadalmi kapcsolat tartásához, ahogy Castells (2005 [1996]: 533) fogalmaz, a helyek tere helyét az „áramlások tere” (space of flows) veszi át. Blokland és Savage (2008) amellett érvelnek, hogy a társadalmi tőke statikus, erőforráskészlet-jellegü megközelítése helyett egy folyamatosan változó decentralizált és diffúz társadalmi folyamatról van szó: a közösségek sem csupán egy adott helyen megtalálható emberek összességei, hanem különböző hálózatok részei. A kulturális határok nem esnek egybe a földrajziakkal, és maguk a határok sem állandóak: a társadalmi tőke áthidalja a földrajzi határokat. A globális világban a kapcsolatháló Los Angelestől Tokióig futhat, és nem a helyi közösség a társadalmi tőke alapja. Sokszor két földrajzilag távol eső hely magas társadalmi státusú lakosaiban több a közös, mint az adott városrész gazdagabb és szegényebb lakói között, ahogy azt Gupta és Ferguson Bombay és London esetében kimutatták (idézi: Blokland és Savage 2008: 9). Ugyanakkor az európai nagyvárosok „globális burzsoáziája” (a felső jövedelmi decilisbe tartozó mérnökök és menedzserek) kutatása alapján ezen rétegeknek még mindig fontosabbak a tényleges (nem virtuális) baráti találkozók. Egy sürü, zárt homogén, helyben gyökerező, de szelektív kapcsolatháló a jellemző, de a szomszédsággal nincs kapcsolatuk (Andreotti és Le Galès 2008).

Tehát a földrajzi határok (akár a nemzetállamoké, akár a régióé, akár egy-egy városrészé) ma már nem feltétlenül jelentik egy adott társadalom vagy közösség határait is. Másfelöl egy adott, lehatárolt tér és a közösség nem szükségszerüen fedik egymást. A fizikai közelség nem biztos, hogy társadalmi kapcsolatot eredményez, föként nem a globalizációs feltételrendszerben. A mai világban a „városi gettó”, azaz az azonos társadalmi helyzetüeket tömörítő városon belüli szigetek jelensége nem csak a szegénynegyedekre jellemző, de a befolyásos jól menő szomszédságok is be tudnak ékelődni a városi szövetbe úgy, hogy attól teljesen elzárkózzanak. Biztonságos „buborékokban” élnek, elkülönülve a „veszélyes külvilágtól”. A közlekedés és az IKT fejlődése lehetővé teszi számukra, hogy minimalizálják az otthonon és a munkahelyen kívüli társadalmi interakciókat, ami szelektív társadalmi érintkezést és a civil elköteleződés teljes hiányát eredményezi, ezáltal a sokféleség elfogadása és az empátia nem fejlődik ki bennük (Atkinson 2008). Emellett a kisebb, zárt tér nem jelent automatikusan ,jó szomszédságot" - negatív, kirekesztő társadalmi következményekkel is járhat (pl. a pletyka 
zárt közösségekben sokkal erősebben van jelen), a napi rutin jellegü találkozás nem szükségszerüen jelent személyes kapcsolatot és mozgósítható erőforrást (Blockland és Savage 2008).

A várospolitika a posztmodern kor társadalmi szétesésével, a szolidaritás és a kollektív cselekvés csökkenő mértékével szemben egy „mindenre jó, általános kúraként” kezdte használni a társadalmi tőkét. Ezen várospolitikai programok előfeltételezése, hogy a kapcsolathálók növelése és a helyi részvétel aktivizálása társadalmi tőkét visz a deprivált térségekbe. Eszerint a területileg szervezett társadalmi töke növeli a negyed élhetőségét, növeli az együttmüködési készséget és hatékonyabbá teszi a közös cselekvéseket (lásd Putnam), a diverz szomszédság, a bizalom és együttmüködés helyi formáit tartalmazó kapcsolatháló az élhető városrész alapja. Boltanski és Chiapello (2005) - az 1960-1990 között keletkezett várospolitikai dokumentumokat vizsgálva - arra jutottak, hogy jelentős emelkedést mutatott azok száma, akik a társadalmi hálózatokra önmagában értékként tekintettek (függetlenül a hálózatok által elért eredményektől). A hálózatok és a társadalmi tőke építése önmagában értékké vált, kapcsolódva a fenntartható közösségek, integráció és kohézió jelszavaihoz.

Ezzel szemben a városszociológiai kutatások azt mutatják, hogy a társadalmi kapcsolatok - és különösen az összekötő társadalmi tőke erősítésére tett várospolitikai beavatkozások - nem feltétlenül járnak a várt eredménnyel. Az összekötő társadalmi tőke éppúgy lehet kirekesztő, amennyiben például a magasabb társadalmi státuszú szomszédság elkülöníti, hogy az alacsonyabb státuszú negyed lakói közül kikkel köti össze magát (a „bevonhatók”) és kikkel nem (a „kívülállók”) (Blokland 2008). A társadalmi tőke határokat teremt és tart fent. Például a dzsentrifikánsok kisajátíthatják a teret azáltal, hogy sztenderdeket fogadnak el arra vonatkozóan, hogy a köztéri alkoholfogyasztás az egyik esetben (fehér középosztályiak szomszédsági piknikje) elfogadott, míg a másik esetben (hajléktalanok barna zacskóba csomagolt sört isznak) elítélendő tevékenységként értelmezi (Blokland és Savage 2008). A vidékkutatások alapján sem egyértelmü a társadalmi tőke pozitív hatása (Megyesi 2014, 2015; Csurgó és Megyesi 2016).

\section{A dzsentrifikáció}

A dzsentrifikáció fogalmát a szakirodalomban elsőként Ruth Glass használta az 1960-as évek elején a londoni East Enden tapasztalt jelenségek leírására (Glass 1964) Maga a fogalom az angol gentry szóból képződött, melyet eredetileg a Jane Austen-regények világából ismert (Redfen 2003) nem arisztokrata származású vidéki földtulajdonos rétegre használtak, utalva annak feltörekvő középosztályi jellegére.

Az 1960-as években London zömmel 19. századi belső kerületeinek egy részében és a hagyományos munkáskerületekben a jobb módúak kiköltözése után ott maradó szegényebb lakosok nem voltak képesek házuk felújítására, illetve az olyan magas lakbérek fizetésére, hogy a háztulajdonosok érdemesnek tartsák modernizálni a lakásokat. Ezt a slumosodási jelenséget állította meg, illetve fordította vissza egy kezdetben csak helyi lakáspiaci anomáliának vélt jelenség. Ruth Glass eredeti leírása szerint:

London munkások lakta negyedeit egymás után szállják meg a középosztály tagjai, alsó és felső középosztályiak egyaránt. A bérleti szerződések lejártakor átvették a szegényes lakóépületeket és szerény házakat - két szoba a földszinten, kettő az emeleten -, és elegáns, drága lakásokká alakították át. A nagyobb Viktória-korabeli házak, amelyek már régebben vagy csak nemrégiben leértékelődtek és bérházként vagy soklakásos épületként maradtak fenn, újra felértékelődtek. 
(...) Ha a „dzsentrifikáció” folyamata egy kerületben megkezdődik, gyorsan terjed, egészen addig, míg a néhai munkásosztályi lakosokat egészen ki nem szorítják, és a kerület társadalmi karaktere teljesen át nem alakul (Glass 1964: xvii-xix, saját fordítás).

A nyugati szakirodalomban ezt követően a dzsentrifikáció témája több évtizeden keresztül népszerủ volt, számos elméleti és módszertani vita alakult ki körülötte. A különböző diszciplínák (közgazdaság-tudományi, földrajzi, szociológiai) és elméleti paradigmák (kritikai, neomarxista, neoweberiánus) eltérő álláspontokra jutnak a dzsentrifikáció okait, szereplőit és eredményeit illetően. A dzsentrifikáció magyarázó modelljeit tekintve alapvetöen két nagy irányzat különböztethető meg: az egyik szerint az emberek, a másik szerint a tőke az, ami irányítja a folyamatot. Ennek a kettősségnek számos megfogalmazása létezik: termelés/fogyasztás, tőke/kultúra, kínálat/kereslet, marxista/liberális magyarázatokként szoktak utalni rájuk (Atkinson és Bridge 2005). A megközelítések egyik csoportja az életmód, életstílus és a kultúrához való viszony jellegzetességeit hangsúlyozza, míg másik csoportja elsősorban a tőke mozgásának tulajdonítja a dzsentrifikáció megjelenését.

A dzsentrifikáció a legtöbb meghatározás szerint olyan folyamat, melynek során a város belső részein fekvő korábbi szegény és munkásosztályi, gyakran etnikai kisebbségek által lakott negyedekbe ezen részek felújitásán keresztül középosztályi ingatlanvásárlók, bérlők áramlanak be, és a negyed fizikai és demográfiai, társadalmi szerkezete átalakul. Ennél „keményebb" megfogalmazások szerint nemcsak új rétegek áramlanak be, hanem a régieket ki is szorítják, azaz kimondottan lakosságcseréröl beszélhetünk (Hamnet 1991; Smith 1996: 32; Tomay 2007, 2008).

Az 1990-es évektől megindult második, posztrecessziós dzsentrifikációs hullámban kulcsfontosságú az a várospolitika, amely a dzsentrifikációt a belvárosok gondjainak általános „orvosságaként” alkalmazza. Ezen időszakban megindult a dzsentrifikáció terjedése a globális városoktól a periféria felé, így megjelent többek közt Kelet-Európában is.

\section{A vidéki dzsentrifikáció}

A városszociológiai irodalomban nagy karriert befutott dzsentrifikációs elmélet mellett a vidék dzsentrifikációját csak az utóbbi évtizedekben kezdték el felismerni és kutatni, azóta azonban kutatása világszerte elterjedt: az Egyesült Államoktól Európán és Oroszországon keresztül egészen Kínáig és Ausztráliáig találni a dzsentrifikációs megközelítést alkalmazó vidéki szakirodalmakat (Philips 1993; Stockdale 2009; Alonso González 2017; Mamonova és Sutherland 2015; Junxi Qian, Shenjing He és Lin Liu 2013; Holmes és Argent 2016). A város és a vidék dzsentrifikációja természetesen nem egy és ugyanaz a jelenség, a vidéki kistelepüléseken megjelenő középosztályi csoportok leírásakor nem egyszerủen a városi dzsentrifikációfogalom átvételéről van szó, ugyanakkor Philips $(1993,2005)$ felhívja a figyelmet a párhuzamokra a város és a vidék posztindusztriális átalakulása között. A vidék dzsentrifikációjának lényege, hogy városi felső és középosztályi csoportok költöznek természeti és társadalmi értékeik miatt vonzó vidéki településekre, ennek következtében a települések mind gazdasági, mind társadalmi értelemben felértékelődnek, illetve a városi fogyasztók a saját értékeik és vízióik szerint alakítják át a helyi adottságokat, az épített és a természeti környezetet (Kovách 2012). Az egyik legföbb különbség a vidék és a város dzsentrifikációja között, hogy a vidék dzsentrifikációjában központi figyelmet kap a termé- 
szet, míg a városi dzsentrifikáció „idillje” az esztétizálható múlttal rendelkező épített környezet. A vidék dzsentrifikációjában nagy szerepet kap, hogy a kiköltöző (gentrifier) vonzódik a vidéki tájhoz, természethez, növény- és állatvilághoz, mezőgazdasághoz, és ez meghatározza az életmódját (lovaglás, vadászat, golf) is (Csurgó 2013). A vidék dzsentrifikációja szoros kapcsolatban van a turizmus vidéki fordulatával, amikor egy-egy megkapó természeti környezetben fekvő település vagy térség eleinte turisztikai célpontként válik ismertté, majd a városiak által felvásárolt nyaralók, második otthonok egyre inkább elsődleges otthonaivá válnak az új tulajdonosoknak (Solana-Solana 2010; Leebrick 2015).

\section{Osztály, rend, státuszcsoport, habitus}

A dzsentrifikáció szereplői a legtöbb meghatározás szerint jövedelmük és iskolázottságuk alapján középosztályiak, értékrendjük, kevésbé konzervatív nézeteik, kulturális fogyasztásuk mégis eltér a „régi” (jellemzően a szuburbán életmódot választó) középosztályétól (Gans 1995; Lees 2000). Kérdés, hogy mitől jelennek meg új lakóhelyi és kulturális-fogyasztási preferenciák a középosztály egy részénél, mivel a párhuzamosan zajló szuburbanizációs folyamatok egyértelműen bebizonyították, hogy nem a középosztály egésze fordul a belvárosok felé.

Az „új középosztály” elmélete (Ley 1996; Butler 1997) szerint a középosztály kulturális fragmentációjának térbeli leképeződése a dzsentrifikáció. Ley a kulturális és fogyasztási szokások megváltozásával magyarázza a dzsentrifikációt. Magyarázatában a fő faktor, hogy a szellemi dolgozók arányának növekedésével egy „új középosztály” alakult ki, amely keresleti nyomást jelent a belvárosi ingatlanpiacon.

$A z$ „új osztály” koncepcióját kritizálta és finomította Redfern (2003). Ö is arra a problémára próbált választ találni, hogy hogyan lehetséges, hogy a dzsentrifikáció résztvevői ugyanabból a gazdasági osztályból származnak, ugyanazok a motivációik, mint a szuburbok lakóinak - az identitás kialakítása és megőrzése a modern világban -, csak abban különböznek, hogy milyen eszközökkel valósítják meg ezt. Redfern szerint a fő problémát az osztály és a státusz megfeleltetése okozza. A szerző definíciója szerint az osztály gazdasági kategória, a nem gazdasági tőkéket - pl. Bourdieu kulturális tőkéjét - a weberi státuszkoncepció ${ }^{3}$ alá sorolja be. Ezért aztán a szerző szerint a dzsentrifikánsok nem „új osztály”, inkább státuszcsoport, nem annyira az attribútumaik, mint az attitüdjeik különböznek. Redfern szerint fontos a divat szerepe: a szuburbok lakói és a dzsentrifikánsok különböző státuszcsoportok tagjai, a lakhatást pedig státusszimbólumként használják, világosan tudtára adva mindenkinek hovatartozásukat. Redfern szerint ez magyarázza a modern világban a divat fontosságát, mert az lehetőséget teremt arra, hogy mások legyünk, de ne nagyon mások. Ezt a törekvést tükrözi a ruházkodás, a zenei ízlés, az étteremválasztás, és ez magyarázza az otthon, a szomszédság megválasztását is: olyannak akarjuk őket, ami mond rólunk valamit.

Itt említenék meg egy fontos tényezőt, amely számos tanulmányban visszaköszön, mint a dzsentrifikált réteg összekötő kapcsa, és ez a kommenzalitás, vagyis a közös étkezés. Ahogy Collins (1998) fogalmaz, minden közös étkezésnek van rituális jellege: csoportot hoz létre, és elhatárolja a tagokat a kívülállóktól. Akár abban a formában jelenik meg, hogy a saját

3 Weber a rendeket vagy státuszcsoportokat elsősorban a fogyasztás módja szerint definiálja, az egyes rendek sajátos életstílust valósítanak meg, a hasonló életstílus egységet hoz létre, még akkor is, ha a rend tagjai eltérő gazdasági körülmények között élnek. 
otthonukba kit hívnak meg vacsorára (Butler 2008), akár úgy, hogy milyen éttermeket, kávézókat részesítenek előnyben, melyek azok a „gasztronómiai oázisok” (Neal 2006), ahol a dzsentrifikánsok nap mint nap találkoznak és ismerkednek egymással. A közös asztalnál étkezés kritériuma alapján (is) a weberi értelemben vett rendet alkotnak a dzsentrifikánsok.

A középosztályon belüli elkülönülést, eltérő preferenciákat Zukin (1987), Bridge (2001) és Butler $(2002,2008)$ is Bourdieu habituselméletének segítségével igyekszik magyarázni. ${ }^{4}$ Zukin szerint ugyan jövedelmüket és iskolázottságukat tekintve sem különíthetők el a dzsentrifikánsok a középosztály más részeitől, attitüdjeik, értékválasztásaik azonban eltérőek. Számukra fontos, hogy a régi történeti múltú helyekhez közel éljenek, hogy közel legyenek a munkahelyeikhez, hogy lehetőségük legyen szórakozni a közelben, legyen mozi, színház a környéken, és hogy munka után be tudjanak ugrani valahová egy kávéra.

Bridge (2001) szerint a dzsentrifikáció kezdeti szakaszában a beköltözők - Bourdieu fogalmi keretében értelmezve - kevesebb materiális tőkével és több kulturális tökével rendelkeznek. Azok a középosztályiak, akik beköltöznek a belvárosba, habitusukban ${ }^{5}$ térnek el a szuburbokban élőktől. Bridge szerint a tipikus dzsentrifikáns „pionír” az alulfizetett, állami szektorban dolgozó értelmiségi munkavállaló, akinek önmeghatározása jelentősen különbözhet az üzletemberekétől. Ők indítják el a dzsentrifikációs folyamatot, az ő mozgásukat követi a többieké. A Bridge-féle módosított habituselmélet szerint az adott osztályban (jelen esetben a középosztályon belül) van egy csoport, amely vállalja a nehézséget, hogy viselkedése a középosztály hagyományos életstílusától, habitusától való eltérés miatt látványossá válik. Ez a csoport, melynek tagjai a dzsentrifikáció elindítói, tisztában van társadalmi helyzetével, a dzsentrifikáció során pedig a tér szimbolikus dimenziójával fejezi ki ezt az eltérést (amit követ a kulturális fogyasztás más téren történő változtatása is). Az új osztály önreflexív természete mutatkozik meg abban, hogy tagjai egyedi minőségre vágynak. A rossz állapotú házak vásárlásában az önkifejezés lehetősége rejlik, hiszen azokat saját ízlésük szerint tudják átalakítani. Az osztály elkülönülésének fontos része, hogy az épületek megfeleljenek a „jó ízlésnek", azaz térjenek el mind a munkásosztály modernizációs törekvéseit szimbolizáló építményektől, mind a tradicionális középosztály eleve modern, standard otthonaitól. Miután a beköltöző „városi középosztály” módosította habitusát, kialakította a megkülönböztető ízlésvilágot, a következő beköltözők döntéseit ez befolyásolja, míg végül a belvárosban lakhatás egy vágyott szimbólum lesz, az új identitás szimbóluma. A „pionírok” döntése persze kockázatos, és ki vannak téve annak a kellemetlenségnek, hogy döntésük látványos. Ez a gondolat társadalomelméleti magyarázatot próbál adni a dzsentrifikációra: egy adott csoport eltérő szemlélete a lakóhely-megváltoztatás motivációja, ezzel szimbolizálják a középosztály más csoportjaitól eltérő habitusukat.

Butler (2002) szerint létezik „nagyvárosi habitus”, ez különíti el a városelhagyó és a városban maradó középosztályt. A „nagyvárosi habitus” által jellemzett dzsentrifikánsok magasan iskolázottak, a nagyvárosban dolgoznak, vonzza öket a kulturális infrastruktúra és a hasonlóakhoz való közelség, de köztük is vannak eltérések: az egyes dzsentrifikált városrészeket eltérő „minihabitusok” jellemzik. Butler és Robson (2003) - London dzsentrifikált

4 Arról, hogy miért kézenfekvő Bourdieu habituskoncepciójának alkalmazása a városszociológiai folyamatok megértésében, részletesen ír Berger (2018).

5 A habitus azon öröklött diszpozíciók együttese, amelyek meghatározzák, hogyan viselkedünk bizonyos helyzetekben, anélkül, hogy tudnánk ezt. Így tarthatók fenn az osztályra jellemző viselkedésminták, ezzel őrzi meg az osztály státuszát, ehhez az kell, hogy az ízlések öröklődjenek (Bourdieu 2010 [1979]). 
negyedeit vizsgáló tanulmányukban - amellett érvelnek, hogy a lakóhely kiválasztásában - az anyagi lehetőségeken túl - fontos szerepe van az életstílus kifejezésének, az identifikáció része ez, melynek során olyan negyedeket keresünk, ahol hozzánk hasonló emberek élnek. A dzsentrifikáció résztvevői jellemzően nem strukturált munkarendben dolgoznak, az infokommunikációs eszközök fejlődésével a földrajzi határok, távolságok elvesztették jelentőségüket, ezáltal a tér és az idő összezsugorodott, ami a biztonság hiányának érzetét kelti bennük. E struktúrahiánynak, a magánszféra és a munka világa elkülönítésének a kifejezését hivatott szolgálni a dzsentrifikációban részt vevő családok lakóhelyválasztása. Emellett számukra fontos része a dzsentrifikációs folyamatnak egyfajta „nosztalgikus múlt” felépítése, helyi közösségteremtés, helyi értékek megőrzése, újrafelfedezése. Ezt egy relatíve öntudatos stratégiával érik el, gazdasági, kulturális, társadalmi tőkéjük és habitusuk szerint választanak lakóhelyet. Kutatásuk eredményei szerint a „kozmopolita” és „helyi” identitás ma már nem különül el, a londoni dzsentrifikánsok részei a globális „nagy társadalomnak”, amelynek káros hatásait „helyi” megoldásokkal kompenzálják.

Butler szerint a Belső-Londonra jellemző, zömmel egyéni és kisbefektetők által létrehozott dzsentrifikáció egy kollektív társadalmi cselekvés eredménye, míg a Docklands nagyberuházása alapvetően a tőke dzsentrifikációja (Butler 2008). A különböző városrehabilitációs beavatkozások a dzsentrifikáció különböző típusait eredményezik (lásd még Tomay 2008). A Docklands regenerációja a smithi értelemben vett „revansista” dzsentrifikáció példája, míg ahol a kollektív társadalmi cselekvés eredménye a dzsentrifikáció, ott nem egységes a társadalmi tőke alakulása sem, ezáltal helyi habitusok alakulnak ki (Butler 2002, 2008).

\section{Dzsentrifikáció és társadalmi tőke}

A dzsentrifikációnak az (összekapcsoló) társadalmi tőkére gyakorolt hatásait vizsgáló irodalmak legnagyobb része azzal foglalkozik, hogy a dzsentrifikációban részt vevő (felső)középosztályi rétegek miként „terjesztik ki” társadalmi tőkéjüket az általuk elfoglalt vagy azzal szomszédos területen élő alsóbb társadalmi helyzetü lakóira, hogyan mozgósítják - vagy épp ellenkezőleg, tartják vissza - az általuk birtokolt relatíve magasabb mértékü társadalmi tőkét a szomszédság vonatkozásában.

Blokland (2008) etnográfiai elemzést végzett az összekötő társadalmi tőke alakulásáról egy kudarccal végződött New Haven-i kertszépítési program keretében, melyben az alacsonyabb státuszú feketék lakta terület szomszédságába költözött középosztályi betelepülők önkéntes alapon projektet szerveztek a negyed szépítésére, miközben céljuk volt a helyi részvétel, aktivitás növelése, a közösségépítés is. Blokland egyik fö kérdése, hogy hogyan müködik a társadalmi tőke, miért fektet be energiát egy magasabb társadalmi státuszú az önkéntes projektbe, ha tudja, hogy nem kap majd viszonzást sem társadalmi tőke, sem elismerés vagy növekvő önbecsülés formájában. Blokland szerint a részt vevö önkéntesek viselkedése nem irracionális, hanem egy ideológia kifejeződése a részükről: a dzsentrifikáció korai szakaszában részt vett emberek azt választották, hogy a városban élnek annak diverzitása miatt. Tehát kulturális, politikai és morális értékek vezették őket a cselekvésre (lásd Weber, Mannheim). A dzsentrifikáció eszerint nemcsak ingatlanberuházás, funkcionális döntés, hanem egy kulturális politikai önkifejezés is a szuburbokkal szemben és a kozmopolita városközponti lehetőségek mellett. A középosztályon belüli törés ezáltal az identitásuk részévé 
válik (lásd Ley 1986, 1996). Blokland szerint a dzsentrifikánsokat értékeik, iskolázottságuk és politikai kultúrájuk mobilizálta a cselekvésre. Nem személyes érdekből, hanem egy közös meggyőződés miatt aktivizálták társadalmi tőkéjüket, de ez nem jelentett bizalmat vagy személyes szívességeket, hitelépítést a szegénynegyed lakói felé. Blokland meglátása alapján valamit közösen csinálni nem egyenlő a közösségépítéssel, a társadalmi tőke külön-külön a dzsentrifikánsok és a szegénynegyed lakói között működött, de az etnikai és társadalmi falakat nem lépte át.

Butler (2008) a társadalmi tőke bourdieu-i és putnami fogalmát is használta a londoni dzsentrifikáció vizsgálatában. Kérdései, hogy hogyan kerül a hátrányos, föleg megkötő társadalmi tőke helyébe részben vagy egészben az összekötő társadalmi tőke a dzsentrifikáció során, valamint hogy a relatíve privilegizált dzsentrifikáns réteg hogyan tudja a hatalmát és privilégiumait fenntartani: a dzsentrifikáns középosztály a szomszédság szintjén megőrzi az előnyös pozícióját, vagy a társadalmi és kulturális tőkéjüket megosztják a szomszédsággal és ők is profitálnak belőle? Azaz az összekötő társadalmi tőkét megoszthatják-e helyben anélkül, hogy feláldoznák a társadalmi elönyöket? És ha így is van, miért teszik ezt?

Butler a putnami társadalmitőke-készletet vizsgálta, esettanulmánya alapján a korábban deprivált környékek kisebb-nagyobb mértékű dzsentrifikációs átalakulásával a régi munkásosztályi közösség felbomlott, és új, középosztályi társadalmi kapcsolatháló épült. A putnami társadalmi tőke leginkább a közösségi önkéntes szervezetekben van jelen, ami az 1960-as évek munkásosztályát jellemezte leginkább. Ez a típusú tőke mindenhol csökkent, mivel a középosztályi beköltözők civil, helyi aktivitása (szervezeti tagsága) alacsony mértékű, számukra nem a szomszédság, hanem a jellemzően azonos nemü, korú, etnikumú és társadalmi státuszú barátaik a fontosak.

A bourdieu-i értelemben vett társadalmi tőke a társadalmi kapcsolatokon keresztül épül fel és a viszonyok adják a lényegét. A bourdieu-i tőkéket vizsgálva Butler azt találta, hogy a szimbolikus kulturális tőke az, ami képes definiálni és legitimálni a kulturális, morális és esztétikai értékeket. A belső londoni területek esetén a magas kulturális tőke tette lehetővé, hogy megbecsüljék a múlt és a kézmüves hagyomány jelentőségét, ami a viktoriánus, alsó középosztályi épületekből áradt. Butler szerint ez a dzsentrifikáció lényege: egy terület átalakítása a kisebbségben lévő középosztály elképzelései szerint.

Arról kevesebb szó esett mindeddig, hogy a dzsentrifikációban részt vevő rétegek egymással való kapcsolódása, illetve a dzsentrifikáció különböző hullámaiban részt vevők egymásra rétegződése az adott városrészben, szomszédságban milyen hatással van az összekötő társadalmi tőkéjükre.

\section{Hullámok és hidak}

Ahogy a dzsentrifikáció újabb és újabb hullámai egymásra következtek, úgy módosult a benne részt vevők köre is. A kutatások szerint egy-egy lerobbant városrész divatossá tételében, a dzsentrifikáció megindulásában sokszor szerepe van a művészeknek és bohémeknek, akik saját helyzetük stabilizálása érdekében költöznek ezen központhoz közeli, de olcsó területekre, többnyire ők hozzák divatba a korábban lepusztult városrészt, ez indítja el az ingatlanbefektetői érdeklődést, beruházásokat, és ezután érkeznek a területre a szélesebb középrétegek (Savage és Warde 1993). 
A lakosságcsere fokozatos. Kezdetben jönnek a még anyagilag és művészileg a peremen elhelyezkedő művészek, és általában azok az emberek, akiket szerény anyagi eszközeik, nagy térigényük és az elővárosi házak és élet egyhangúsága arra késztet, hogy a koszos és veszélyes, polgári értelemben lakhatatlan utcákban fokozott érzékenységgel egy másfajta, színesebb élet lehetőségét lássák meg. Megkezdődik a házak, lakások felújítása - az érdekes belső terek iránti igény és a pénzhiány okán általában saját erőből. A New York-i Soho-beli vagy Lower East Side-i tömeges mủvészlakásmód kialakulása jól mutatja, hogyan válik az eleinte periferiális életmód- és mủvészeti mozgalom tömeges ingatlanpiaci mozgássá. Az avantgárd művészeket elkapja a fóáram, a városnegyed veszélyes élete pedig nyárspolgári létformává csendesül (Bodnár 1996).

Az első dzsentrifikációs hullámban részt vevő „úttörők” vagy „pionírok” gyakran életformájukban, értékeikben tértek el a szuburbanizált középosztálytól. Hasonló jövedelemszint és iskolázottság mellett (értelmiségi réteg, főként kreatív foglalkozásúak) az választotta el őket a középosztály többi részétől, hogy bár nem igazán voltak gazdagok, a lerobbant, de már feljövőben lévő belvárosba költözéssel lehetőségük nyílt egy speciális magas státuszú fogyasztásra, kvázi nagypolgári társadalmi újratermelésre. Ezek az emberek szeretnek gyalog vagy biciklivel munkába járni ahelyett, hogy órákat utaznának szuburbán lakóhelyükröl, a bevásárlóközpontok helyett a specializált kisboltokat választják, értékelik a városban elérhető kulturális és szórakozási lehetőségeket (Zukin 1987).

A dzsentrifikáció újabb hullámaiban részt vevő szereplők az egyre magasabb státuszú „városi gerillák” (Lees 2000). A magasan iskolázott, magas jövedelmű felső középosztályi, gyakran egyszemélyes vagy kis létszámú háztartásokban élö ${ }^{6}$ fiatal betelepülők, a yuppie- $\mathrm{k}^{7}$ belvárosba költözése mögött elsősorban a munkahelyeiket jelentő nemzetközi cégek térbeli mozgása, belvárosba telepedése a meghatározó. Lees (2000) szerint az 1990-es évek végétöl a globális városokban már kimutatható az 1970-es években dzsentrifikált területek redzsentrifikációja is, azaz „szuperdzsentrifikáció” zajlik: ügyvédek, pénzügyi tanácsadók és banki szakemberek és menedzserek - akik a belvárosban vesznek ugyan lakást, de érzelmileg nem kötödnek ahhoz, a városon kívül is van házuk, és nagyon mobilak - beköltözése a korábban dzsentrifikált területekre. A dzsentrifikációs folyamat újabb hulláma már szélesebb rétegeket érint. Mára egyre kevésbé jellemző, hogy csak a fehér, középosztálybeli fiatalok vesznek részt a folyamatban, a belvárosok dzsentrifikációjában megjelent a fekete középosztály ${ }^{8}$ és a családos dzsentrifikáció is.

Márpedig ennek a két rétegnek (kreatív foglalkozású, művész és értelmiségi, illetve a magasabb jövedelmü pénzügyi szektorban vagy menedzserként dolgozó csoportnak) a dzsentrifikációs folyamatba való belépése a legtöbbször (legalábbis a globális világvárosok kivételével) nem eredményez azonnali kiszorítást, sokkal inkább egymásra rétegződésről, találkozásról van szó közöttük. Ebben az esetben a társadalmi tőke megosztása sem olyan féloldalas, mint a középosztályi dzsentrifikánsok és a szegényebb szomszédaik között, mivel a társadalmi interakcióval mindkét fél kap valamit. Mivel többnyire a pionír dzsentrifikánsok saját elképzeléseik szerint formálják át a negyedet és teszik azt divatossá (és most tekintsünk

6 DINKY = Double Income No Kids Yet, azaz gyerektelen kétkeresős háztartások.

7 A Young Urban Professional rövidítése, a városközpontban, szolgáltató szektorban dolgozó, 20-as éveik második, illetve 30-as éveik elején járó, jól kereső felső középosztályi réteg. A '80-as évek elején bevezetett „yuppie” fogalma a korábbi „hippi” ironikus visszhangjaként jelent meg.

8 Lees szerint az új dzsentrifikálók közé tartoznak a harmadik világból származó emigránsok, akiket a világvárosok vonzanak, a feketék és más kisebbségiek, akik nem a folyamat áldozatai, hanem aktív résztvevői. 
el a városrehabilitáció és városmarketing által generált nagyprojektektől), a magasabb jövedelmű rétegek ezen divatosság alapján kezdik el használni az adott környezetet és követik az új életstílust - ugyan felértékelik a városrészt, és az árak növelésével valóban ki is szorulhatnak belöle a pionírok, de ez nem jellemző. Ugyanakkor a kevésbé tőkeerős - de kreatív ötletekkel, új kezdeményezésekkel teli - réteg számára gyümölcsöző lehet olyan partnerre találni, aki képes a kezdeményezéseik mögé állni, és beindításukhoz anyagi forrásokat biztosítani vagy hitelezni. A „gyümölcsöző kapcsolatoknak” azonban itt még távolról sincs vége, hiszen a kreatív foglalkozású, müvész és értelmiségi dzsentrifikánsok koncentrációja az adott városrészben és az általuk látogatott kitüntetett közösségi terekben önmagában is olyan kapcsolathálók, együttmüködések létrejöttét eredményezheti, amelyek elősegítik a vállalkozások és az innovációk sokasodását az adott helyen. Mivel egyelőre szisztematikus kutatást nem végeztem ezen a téren, az alábbiakban egy-egy példával fogom illusztrálni a fentiek müködését a gyakorlatban.

\section{A gasztrofalu, a bulinegyed és a 100 éves házak}

A találkozási, közösségi csomópont - azaz a társadalmi tőke termelésének színtere - számos módon létre jöhet akár a dzsentrifikált városrészekben, akár a vidékeken. Az egyik lehetséges találkozóhelyet, ahol a társadalmi tőke kialakulhat, a kulturális örökségek adják (Murzyn-Kupisz 2013).

Ahogy már korábban szó volt róla, egy adott városrész gasztronómiai kínálata erős összefüggést mutat az ott lakók igényeivel: a pionír dzsentrifikánsok (művészek, értelmiségiek), vagy Florida fogalmával élve a kreatív középosztály igényeinek megfelelő vendéglátóhelyek az olyan kávéházak, ahol a helyi zenészek lépnek fel, ahol a wifi lehetőséget teremt a kávézóban laptopon végzett munkára, és ahol esetenként társas összejöveteleket rendeznek. A különböző nemzetek konyháját kínáló vendéglátóhelyek is vonzóak számukra, részben, mert kedvelik a sokszínű népesség által lakott városrészeket, részben, mert ez számukra egy "gasztronómiai utazást” biztosít, valamint ilyen helyek lehetnek a helyi termékek felhasználásával magas minőséget előállító éttermek is (Neal 2006; Florida 2005).

Kevésbé tünik triviálisnak, de legalább ilyen „forró pontok” lehetnek a vidéki gasztronómiai rendezvények is - és itt most nem a hagyományos kolbászfesztiválokra gondolok. A hét vidéki étterem összefogásából alakult (ma már 16 tagot számláló) Stílusos Vidéki Éttermiség (SVÉT) ilyen alkalmakat teremt, amikor egy-egy vidéki helyszínen rendeznek pár napos összejöveteleket a helyi termelök és borászok, valamint az ország különböző pontjairól érkezett magas minőséget képviselő vendéglátók (éttermek, cukrászdák) részvételével a magas jövedelmű, és a rendezvény szellemiségére nyitott „erősen szűrt” látogatók számára. A ma már évente mintegy 8-10 rendezvénnyel megszólított célközönség ezáltal megismeri az adott tájegység szolgáltatóit, miközben a térben távolabb, de hasonló felfogás szerint müködő vendéglátósok is kapcsolatokat - társasági és üzleti kapcsolatokat is - alakítanak ki egymással. A rendszeres találkozások és a közös projekt megerősíti, összefüzi ezeket a szálakat, mintegy „áthidalva” a földrajzi távolságot. Ezek a kapcsolatok már nemcsak a közös érdeklődésről és a találkozásról szólnak, hanem számos esetben az így keletkezett társadalmi tőke gazdasági tőkévé is konvertálható, amennyiben konkrét üzleti együttmüködések ala- 
kulnak ki a rendezvények nyomán. Így történhet meg például, hogy az egyik legjobb vidéki étteremként nyilvántartott észak-magyarországi étteremben a Villány-Siklósi borvidék egyik kis kézműves borászata termékeit forgalmazzák (saját interjú, 2018).

Máskor az örökség megóvása hozza életre ezeket a közösségeket: a közös akciók közben megismerik egymást, bizalom épül a szereplők, helyi lakosok és kisvállalkozók között. Az örökség gyakran a felújítás katalizátora is, mivel a dzsentrifikációnak fontos eleme a „hely szelleme" és esztétikája (Murzyn-Kupisz 2013). Erre a típusú társadalmitőke-termelésre nyújt példát a régi pesti zsidónegyed bontásos rekonstrukciója nyomán kibontakozott mozgalom - és a városrész azóta megnövekedett turisztikai és dzsentrifikációs vonzereje. A régi pesti zsidónegyed bontásos rehabilitációs tervei sok vihart kavartak a 2000-es évek elején: a müemlékvédelem (KÖH), az értékvédő civil szervezetek (ÓVÁS!) és a Fővárosi Önkormányzat is hangot adtak elégedetlenségüknek, amiért a kerületi önkormányzat a hagyományos városi szövet értékeit figyelmen kívül hagyva telkeit új - a környezetbe gyakran nem illő - ingatlanfejlesztések számára értékesítette. Eközben egy sor új vendéglátóhely (romkocsmák, új éttermek) és bolt (lakberendezési és dizájnüzlet) települt a területre, elsősorban a magasan képzett, alternatív kultúrára nyitott fiatalokat célozva meg. Az interjúkból kiderült, hogy a kutatásba bevont kereskedelmi, szolgáltató, kulturális, szórakoztató, vendéglátó vállalkozások mindegyike számára fontos volt a városrészben rejlő lehetőségek felismerése: a terület központi elhelyezkedése, kulturális öröksége, és a jelenlegi leromlott állapot mellett a megújulás lehetősége (Csanádi et al. 2007). Mindennek hatására ismertté vált és divatba jött a környék, és megindult a területen egy spontán, „úttörö" jellegü dzsentrifikáció, melynek keretében a területre beáramlottak olyan magasan képzett fiatalok, akik itt vettek lakást, amelyet aztán felújítottak abban a reményben, hogy előbb-utóbb a környék is megújul (Tomay 2008). A 2008-as gazdasági válság utáni évek megtorpanását követően gyors ingatlanpiaci és turisztikai felfutás jellemezte a környéket, olyannyira, hogy mára már a legnépszerübb turisztikai (elsősorban a „buliturizmus”) célpontok közé sorolható (Csanádi et al. 2012).

A kulturális örökséget megismerő, bemutató önkéntesség ugyancsak hozzájárul a társadalmi tőke épüléséhez (Murzyn-Kupisz 2013). A 2011-ben indult Budapest100 program pont egy ilyen önkéntes alapon szervezödő „civil városi ünnep”, amely minden évben egy hétvégén együtt ünnepli - az erre nyitott közönséggel és a programhoz csatlakozó lakóközösségekkel - az éppen akkor százéves budapesti házakat. A program célja, hogy „felhívja a figyelmet a körülöttünk lévő város mindennapi értékeire, közelebb hozza egymáshoz a városlakókat, a szomszédokat, a generációkat (...) bemutatni pincétől a padlásig a házakat, megismerkedni a lakókkal és hozzájárulni új közösségek kialakulásához". A Budapest100 eseményeit önkéntesek szervezik a házak lakóinak, illetve a részt vevő intézmények képviselőinek a segítségével. A több díjat ${ }^{10}$ begyüjtött kezdeményezés 1750 zömmel fiatal, egyetemista vagy pályakezdő, a város iránt érdeklődő (építész, művészettörténész, szociológus, várostörténész) önkéntest hozott össze az elmúlt nyolc év során, ezáltal számos személyes és szakmai kapcsolat épült ki a résztvevők között (albérlő és munkalehetőség megtalálásában is segített már az itteni önkéntes munka).

9 www.budapest100.hu.

10 Lebendige Stadt Stiftung (2013), Az Év Önkéntes Programja (2014), SozialMarie (2017), URBACT Good practice award (2017). 


\section{Zárszó}

Összegezve az eddig leírtakat, elmondható, hogy az innovációs és vállalkozási ökoszisztémák egyik fontos peremfeltételét képezi az a társadalmi-kulturális környezet, melyben a vállalkozások és innovációk megvalósulnak. Ez annyit jelent, hogy a gazdasági növekedés motorjaként szolgáló innovációk, kreatív és tudásalapú vállalkozások kialakulásának és fejlődésének megértéséhez, ezáltal serkentésük „receptjéhez” nélkülözhetetlen azon térbeli társadalmi folyamatok feltárása, melyek az új ötletek és vállalkozások melegágyaként szolgálnak. Meglátásom szerint ez nem más, mint a városszociológiában sokat kutatott, de már a vidékszociológiában is azonosított dzsentrifikáció folyamata.

Tekintettel arra, hogy a témában még nem készült empirikus kutatás, a jelen tanulmány a különböző tudományágakhoz, elméleti és kutatási irányokhoz tartozó szakirodalmak öszszefésülésével egyfajta konceptuális keretet kívánt felvázolni egy jövőbeli kutatás számára, melyben empirikus vizsgálat alá vetem a városi és vidéki dzsentrifikáció szerepét, hatásmechanizmusait az összekötő társadalmi tőke (újra)termelésében, továbbá azt, hogy hozzájárul-e ez a folyamat és hogyan az innováció és a vállalkozások fellendüléséhez az adott térségben, illetve városrészben. Hipotézisem szerint a dzsentrifikáció folyamata során - az egymásra rétegződő dzsentrifikációs hullámok eredményeként és a dzsentrifikált városnegyedekben vagy falvakban - jönnek létre azok a társadalmi interakciós helyzetek (közös fogyasztási helyek, étkezések, önkéntes és jótékony akciók, vagy éppen civil megmozdulások keretében), ahol a dzsentrifikációban érintett két nagyobb társadalmi csoport: a magas kulturális tőkével rendelkező középosztályi kreatív és szabadfoglalkozású értelmiségiek, „úttörő dzsentrifikánsok", valamint a magasabb anyagi tőkével (magasabb jövedelemmel) rendelkező felső középosztályi, főként pénzügyi és müszaki területeken dolgozó dzsentrifikánsok megismerkednek és rendszeresen találkoznak egymással, ezáltal (összekötő) társadalmi tőkéjüket növelve barátságokat és üzleti kapcsolatokat építenek ki egymással.

Jelen tanulmányban - elsődleges célkitűzése okán - nem tárgyaltam a dzsentrifikációs folyamatok árnyoldalait, negatív társadalmi következményeit: a szegények kiszorulását a városon kívülre vagy erősen szegregált városrészekbe (Budapest esetében erről részletesen lásd Csanádi et al. 2010; Jelinek 2010), ami szélsőséges esetben akár a város olyan mértékű társadalmi szétszakadásához vezethet, ami a gazdasági fejlődés gátja is lehet (nem beszélve az emberi és társadalmi veszteségekről).

\section{Hivatkozott irodalom}

Alonso González, Pablo (2017): Heritage and Rural Gentrification in Spain. The Case of Santiago Millas. International Journal of Heritage Studies 23(2): 125-140. DOI: https://doi.org/10.1080/13527258.2016.1246468

Andreotti, Alberta és Patrick Le Galès (2008): Middle Class Neighbourhood Attachment in Paris and Milan. Partial Exit and Profound Rootedness. In Networked Urbanism. Social Capital in the City. Talja Blokland és Savage Warde (szerk.). Aldershot: Ashgate, 127-143. Interneten: http://www.stellenboschheritage.co.za/wp-content/ uploads/Networked-Urbanism-1.pdf (letöltve: 2019. február 9.).

Atkinson, Rowland G. (2008): The Flowing Enclave and the Misanthropy of Networked Affluence. In Networked Urbanism. Social Capital in the City. Talja Blokland és Savage Warde (szerk.). Aldershot: Ashgate, 41-58. Interneten: http://www.stellenboschheritage.co.za/wp-content/uploads/Networked-Urbanism-1.pdf (letöltve: 2019. február 9.). 
Atkinson, Rowland G. és Gary Bridge (2005): Gentrification in a Global Context. The New Urban Colonialism. London - New York: Routledge.

Berg, Leo van de et al. (1982): Urban Europe. A Study of Growth and Decline. Vol. 1.

Berger Viktor (2018): Térré szőtt társadalmiság. A tér kategóriája a szociológiaelméletekben. Budapest: L’Harmattan - Könyvpont.

Blokland, Talja (2008): Gardening with a Little Help from Your (Middle Class) Friends. Bridging Social Capital Across Race and Class in a Mixed Neighbourhood. In Networked Urbanism. Social Capital in the City. Talja Blokland és Savage Warde (szerk.). Aldershot: Ashgate, 147-170. Interneten: http://www.stellenboschheritage. co.za/wp-content/uploads/Networked-Urbanism-1.pdf (letöltve: 2019. február 9.).

Blokland, Talja és Mike Savage (2008): Social Capital and Networked Urbanism. In Networked Urbanism. Social Capital in the City. Talja Blokland és Savage Warde (szerk.). Aldershot: Ashgate, 1-20. Interneten: http://www. stellenboschheritage.co.za/wp-content/uploads/Networked-Urbanism-1.pdf (letöltve: 2019. február 9.).

Bodnár Judit (1996): A szakadozó városszövet. Budapesti Negyed (14). Interneten: http://epa.oszk.hu/00000/ 00003/00012/bodnar.htm (letöltve:2019. február 9.).

Bodor Ákos (2013): Az innovációt körülvevő társadalmi kontextus néhány elemének vizsgálata. In Innovációbarát kormányzás Magyarországon. A regionális innovációs fejlesztéspolitika kihívásai. Gál Zoltán (szerk.). Pécs: MTA KRTK RKI, 143-165. Interneten: http://www.regscience.hu:8080/xmlui/bitstream/handle/11155/153/ Gal_2013_innovaciobarat.pdf?sequence=1.

Bodor Ákos, Grünhut Zoltán és Horeczki Réka (2018): Considering the Linkage between the Theory of Trust and Classical Rural Sociology's Concepts. European Countryside 10(3): 482-497. DOI: https://doi.org/10.2478/euco2018-0027

Boltanski, Luc és Éve Chiapello (2005 [1999]): The New Spirit of Capitalism, London - New York: Verso.

Bourdieu, Pierre (1985 [1979]): Distinction. London: Routledge.

Bourdieu, Pierre (2010 [1979]): A habitus és az életstílusok tere. Replika (72): 49-94.

Bridge, Gary (2001): Bourdieu, Rational Action and the Time-Space Strategy of Gentrification. Transactions of Institutions of the British Geographers 26(2): 205-216. DOI: https://doi.org/10.1111/1475-5661.00015

Butler, Tim és Garry Robson (2003): Negotiating Their Way In. The Middle Classes, Gentrification and the Deployment of Capital in a Globalising Metropolis. Urban Studies 40(9): 1791-1809. DOI: https://doi.org/10.10 80\%2F0042098032000106609

Butler, Tim (1997): Gentrification and the Middle Classes. Aldershot: Ashgate

Butler, Tim (2002): Thinking Global but Acting Local. The Middle Classes in the City. Sociological Research Online 7(3): 1-19. DOI: https://doi.org/10.5153/sro.740.

Butler, Tim (2008): Social Capital and the Formation of London's Middle Classes. In Networked Urbanism. Social Capital in the City. Talja Blokland és Savage Warde (szerk.). Aldershot: Ashgate, 217-236. Interneten: http:// www.stellenboschheritage.co.za/wp-content/uploads/Networked-Urbanism-1.pdf (letöltve: 2019. február 9.).

BVTV (1966): Budapesti városszociológiai vizsgálatok. Budapest: Budapesti Várostervező Vállalat.

Castells, Manuel (2005 [1996]): Az információ kora. Gazdaság, társadalom és kultúra. 1. kötet. A hálózati társadalom kialakulása. Budapest: Infonia.

Coleman, James S. (1990): The Foundations of Social Theory. Cambridge, MA: Harvard University Press.

Collins, Randall (1998 [1992]): A státuszkultúrák termelése és a nők. In A kultúra szociológiája. Wessely Anna (szerk.). Budapest: Osiris, 160-173.

Csanádi Gábor, Csizmady Adrienne, Kőszeghy Lea és Tomay Kyra (2007): A városrehabilitáció társadalmi hatásai Budapesten, In A történelmi városközpontok átalakulásának társadalmi hatásai. Enyedi György (szerk.). Budapest: MTA Társadalomkutató Központ, 93-118.

Csanádi Gábor, Csizmady Adrienn, Kőszeghy Lea és Tomay Kyra (2009): Társadalom - Tér - Szerkezet. Budapest: ELTE TÁTK VRKK.

Csanádi Gábor, Csizmady Adrienne, Kocsis János, Kőszeghy Lea és Tomay Kyra (2010): Város-Tervezö-Társadalom. Budapest: Sík.

Csanádi Gábor, Csizmady Adrienne és Olt Gergely (2012): Átváltozóban. Budapest: Eötvös.

Csurgó Bernadett (2013): Vidéken lakni és vidéken élni. A városból vidékre költözők vidékreprezentációja, mindennapi élete és hatásuk a vidék átalakulására: a város környéki vidék. Budapest: Argumentum - MTA TK SZI.

Csurgó Bernadett és Megyesi Boldizsár (2016): Területi integráció és fejlesztéspolitika: Esettanulmány a Vértesi Natúrpark példáján. Metszetek 5(3): 41-63. DOI: https://doi.org/10.18392/METSZ/2016/3/2

Florida, Richard (2003): Cities and the Creative Class. City and Community 2(1): 3-19. DOI: https://doi.org/10. $1111 / 1540-6040.00034$ 
Florida, Richard (2005): Cities and the Creative Class. New York: Routledge.

Florida, Richard (2018): Foreword. In The Next American City. The Big Promise of Our Midsize Metros. Mick Cornett és Jayson White (szerk.). New York: G. P. Putnam's Sons.

Florida, Richard, Patrick Adler és Charlotta Mellander (2017): The city as innovation machine Regional Studies 51(1): 86-96. https://doi.org/10.1080/00343404.2016.1255324

Füzér Katalin (2015): A bizalom társadalomelmélete és a társadalmi tőke szociológiaelmélete. Századvég (78): 5-16. Interneten: https://szazadveg.hu/uploads/media/588f411066d2f/szazadveg-78-tarsadalmi-toke.pdf (letöltve: 2019. február 9.).

Füzér Katalin (2017): A projektesített város. Részvételi városfejlesztés az ezredfordulós Pécsett. Pécs: Publikon.

Füzér Katalin, Gerő Márton, Sik Endre és Zongor Gábor (2005): A társadalmi tőke növelésének lehetőségei fejlesztéspolitikai eszközökkel. Budapest: TÁRKI.

Füzér Katalin, Sik Endre, Gerő Márton és Zongor Gábor (2006): Társadalmi tőke és fejlesztés In Társadalmi riport 2006. Kolosi Tamás, Tóth István György és Vukovich György (szerk.). Budapest: TÁRKI, 335-350. Interneten: http://www.tarsadalomkutatas.hu/kkk.php?TPUBL-A-703/publikaciok/tpubl_a_703.pdf

Gans, Herbert J. (1959): Avult városrészek lebontásának és az ott élő lakosság átköltöztetésének emberi következményei. In Városszociológia. Szelényi Iván (szerk.). Budapest: Közgazdasági és Jogi Könyvkiadó, 414-442.

Gans, Herbert J. (1995): Urbanism and Suburbanism as Ways of Life. A Reevaluation of Definitions utóirat, In Metropolis. Center and Symbol of our Times. Philip Kasinitz (szerk.). New York: New York University Press, 170-195.

Glass, Ruth (1964): London: Aspects of Change. London, MacGibbon and Kee.

Grünhut Zoltán (2018): Innovációs ökoszisztéma társadalomelméleti kontextusban. Tudásmenedzsment 19(2): 33-45.

Hamnett, Chris (1991.) The Blind Men and the Elephant. The Explanation of Gentrification. Transaction of the institutions of the British Geographers. New Series 16(2): 173-189. Interneten: https://www.academia.edu/19572863/ The_Blind_Men_and_the_Elephant_The_Explanation_of_Gentrification (letöltve: 2019. február 9.).

Holmes, John és Neil Argent (2016): Rural transitions in the Nambucca Valley: Socio-demographic change in a disadvantaged rural locale. Journal of Rural Studies 48: 129-142 DOI: https://doi.org/10.1016/j.jrurstud. 2016.06.009

Isenberg, Daniel J. (2010): How to start an entrepreneurial revolution. Harvard Business Review 88(6): 40-50. Interneten: https://institute.coop/sites/default/files/resources/Isenberg\%20-\%20How\%20to\%20Start\%20an\%20 Entrepreneurial\%20Revolution.pdf (letöltve: 2019. február 9.).

Jacobs, Jane (1969): The Economy of Cities. New York: Random House.

Jelinek Csaba (2010). The Phenomena of Displacement and Relocation during the Process of Gentrification in Budapest. Studia Sociologia 55(2): 105-116.

Junxi Qian, Shenjing He és Lin Liu (2013): Aestheticisation, Rent-seeking, and Rural Gentrification amidst China’s Rapid Urbanisation: The Case of Xiaozhou Village, Guangzhou. Journal of Rural Studies 32: 331-345 DOI: https://doi.org/10.1016/j.jrurstud.2013.08.002

Kleinhans, Reinout, Hugo Priemus és Godfried Engbersen (2007): Understanding Social Capital in Recently Restructured Urban Neighbourhoods. Two Case Studies in Rotterdam. Urban Studies 44(5-6): 1069-1091. DOI: https://doi.org/10.1080/00420980701256047

Kloosterman, Robert C. és Joanne P. van der Leun (1999): Just for Starters. Commercial Gentrification by Immigrant Entrepreneurs in Amsterdam and Rotterdam Neighbourhoods. Housing Studies 14(5): 659-677. DOI: https:// doi.org/10.1080/02673039982669

Kovách Imre (2012): A vidék az ezredfordulón. A jelenkori magyar vidéki társadalom szerkezeti és hatalmi változásai. Budapest: MTA TK SZI - Argumentum Kiadó.

Kuti Mónika és Bedő Zsolt (2018): Az egyetemi központú vállalkozói ökoszisztéma és a közösségi finanszírozás kapcsolata. Vezetéstudomány - Budapest Management Review 49(2): 45-52. DOI: https://doi.org/10.14267/ VEZTUD.2018.02.05

Leebrick, Rhiannon A. (2015): Rural Gentrification and Growing Regional Tourism: New Development in South Central Appalachia. In States and Citizens. Accommodation, Facilitation and Resistance to Globalization. Jon Shefner (szerk.). Bingley, UK: Emerald, 215-234

Lees, Loretta (2000): A Reappraisal of Gentrification. Towards a 'Geography of Gentrification' Progress in Human Geography 24(3): 389-408. DOI: https://doi.org/10.1191\%2F030913200701540483

Ley, David (1996): The New Middle Class and the Remaking of the Central City. Oxford: Oxford University Press.

Ley, David (1986): Alternative Explanations for Inner-City Gentrification: A Canadian Assessment. Annals of the Association of American Geographers 76(4): 521-535. DOI: https://doi.org/10.1111/j.1467-8306.1986.tb00134.x

Megyesi Boldizsár (2014): Fejlesztéspolitika helyben. A társadalmi töke és a fejlesztéspolitika összefüggései a vasvári és a lengyeltóti kistérségben készült esettanulmányok alapján. Socio.hu (3). Interneten: https://socio.hu/ 
uploads/files/2014_3/megyesi.pdf (letöltve 2019. április 14.).

Megyesi Boldizsár (2015): A társadalmi tỏke negatív hatásai. Századvég (78): 105-122.

Mamonova, Natalia és Lee-Ann Sutherland (2015): Rural Gentrification in Russia. Renegotiating Identity, Alternative Food Production and Social Tensions in the Countryside. Journal of Rural Studies 42: 154-165. DOI: https://doi.org/10.1016/j.jrurstud.2015.10.008

Murzyn-Kupisz, Monika (2013): Cultural Heritage in Building and Enhancing Social Capital. Journal of Cultural Heritage Management and Sustainable Development 3(1): 35-54. DOI: https://doi.org/10.1108/ 20441261311317392

Neal, Zachary Paul (2006): Culinary Deserts, Gastronomic Oases. A Classification of US Cities. Urban Studies 43(1): 1-21. DOI: https://doi.org/10.1080\%2F00420980500388728

Nemes Ferenc-Szelényi Iván (1967): A lakóhely, mint közösség. Budapest, Akadémiai.

Phillips, Martin (1993): Rural Gentrification and the Processes of Class Colonisation. Journal of Rural Studies 9(2): 123-140. DOI: 10.1016/0743-0167(93)90026-G

Phillips, Martin (2005): People at the Centre? The Contested Geographies of Gentrification. In Contested Worlds. An Introduction to Human Geography. Martin Phillips (szerk.). Aldershot: Ashgate, 313-352.

Portes, Alejandro (1998): Social Capital. Its Origins and Applications in Modern Sociology. Annual Review of Sociology 24: 1-24. DOI: https://doi.org/10.1146/annurev.soc.24.1.1.

Putnam, Robert D. (2000): Bowling Alone. The Collapse and Revival of American Community. New York: Simon \& Schuster.

Ray, Christopher (1998): Culture, Intellectual Property and Territorial Rural Development. Sociologia Ruralis 38(1): 3-20. DOI: https://doi.org/10.1111/1467-9523.00060

Redfern, Paul A (2003): What Makes Gentrification 'Gentrification'? Urban Studies 40(12): 2351-2366. DOI: https://doi.org/10.1080/0042098032000136101

Robert, Lee és Heinz Tuselmann. (2013): Entrepreneurship, Occupational Division and Social Capital Differentials. Journal of Small Business and Enterprise Development 20(3): 661-680. DOI: https://doi.org/10.1108/ JSBED-04-2013-0058

Savage, Mike és Alan Warde (1993): Urban Sociology, Capitalism and Modernity. New York: Macmillan.

Savage, Mike, Warde Alan és Devine Fiona (2005): Capitals, Assets, and Resources: Some Critical Issues. The British Journal of Sociology 56(1): 31-47. DOI: https://doi.org/10.1111/j.1468-4446.2005.00045.x

Savanya Péter (2013): A társadalmi tőke jelentősége a gazdaságban, szerepe az innovációk társadalmi megformálásában. In Innováció. A vállalati stratégiától a társadalmi stratégiáig. Bajmócy Zoltán és Elekes Zoltán (szerk.). Szeged: JATE Press, 140-159.

Schneider, Jo Anne (2017): Social Capital, Community, and Place A Primer. Chrysalis Collaborations. Interneten: http://chrysaliscollaborations.com/wp-content/uploads/Knight-Social-Capital-primer-final.pdf (letöltve: 2019. február 9.).

Sims, Jim (2017): Building an Effective Entrepreneurship Eco-system. Interneten: https://urbact.eu/buildingeffective-entrepreneurship-eco-system (letöltve 2019. február 9.).

Smith, Neil (1996): The New Urban Frontier: Gentrification and the Revanchist City. London - New York: Routledge.

Smorodinskaya, Nataliya, Martha G. Russell, Daniel Katukov és Kaisa Still (2017): Innovation Ecosystems vs. Innovation Systems in Terms of Collaboration and Co-creation of Value. Proceedings of the 50th Hawaii International Conference on System Sciences. Honolulu, HA: 5245-5254. Interneten: https://www.researchgate.net/ publication/317396011_Innovation_Ecosystems_vs_Innovation_Systems_in_Terms_of_Collaboration_and_ Co-creation_of_Value (letöltve: 2019. február 9.).

Solana-Solana, Miguel (2010): Rural Gentrification in Catalonia, Spain. A Case Study of Migration, Social Change and Conflicts in the Empordanet Area. Geoforum 41(3): 508-517. DOI: https://doi.org/10.1016/j. geoforum.2010.01.005.

Stam, Erik (2015): Entrepreneurial Ecosystems and Regional Policy. A Sympathetic Critique. European Planning Studies 23(9): 1759-1769. DOI: https://doi.org/10.1080/09654313.2015.1061484

Stockdale, Aileen (2010) The Diverse Geographies of Rural Gentrification in Scotland. Journal of Rural Studies 26(1): 31-40. DOI: https://doi.org/10.1016/j.jrurstud.2009.04.001

Szerb László és Horváth Krisztina (2016): GEM 2015 Magyarország. Vállalkozások és vállalkozói ökoszisztéma helyzete 2015-ben. DOI: https://doi.org/10.13140/RG.2.2.23616.33282

Tomay Kyra (2007): Városrehabilitáció és dzsentrifikáció Budapesten. In A történelmi városközpontok átalakulásának társadalmi hatásai. Enyedi György (szerk.). Budapest: MTA Társadalomkutató Központ, 119-150.

Tomay Kyra (2008): Dzsentrifikáció Budapesten az ezredfordulón - a belsö-pesti területek átalakulása. (Doktori értekezés.) Budapest: ELTE TáTK, Szociológia Doktori Iskola. Interneten: http://doktori.tatk.elte.hu/2009_Tomay_ Kyra_tezis.pdf (letöltve: 2019. február 9.). 
Tönnies, Ferdinand (1983 [1887]): Közösség és társadalom. Budapest: Gondolat.

Wilson, Patricia A. (1997): Building Social Capital. A Learning Agenda for the Twenty-First Century. Urban Studies 34(5-6): 745-760.

Zukin, Sharon (1987): Gentrification: Culture and Capital in the Urban Core. Annual Review of Sociology 13: $129-147$.

\section{Internetes források}

http://budapest100.hu/

http://www.svet.hu/

https://ovas.hu/

\section{Tomay Kyra}

szociológus, városszociológus, adjunktus, PTE BTK TMI Szociológia Tanszék

A kutatást az Emberi Erőforrások Minisztériumának Felsőoktatási Intézményi Kiválósági Programja finanszírozta, a Pécsi Tudományegyetem 4. tématerületi „A hazai vállalatok szerepének növelése a nemzet újraiparositásában” programja keretében (szerződés száma: 20765-3/2018/FEKUTSTRAT) 